\title{
Tourism Impacts on the Quality of Life in Hong Kong
}

\author{
Huijun Yang ${ }^{1}$, Grace Chan Suk $\mathrm{Ha}^{1} \&$ Wenjie $\mathrm{Li}^{2}$ \\ ${ }^{1}$ Faculty of International Tourism and Management, City University of Macau, SAR, China \\ ${ }^{2}$ Guilin Institute of Tourism, 26 Lianfeng Road, Gulin, Guanxi province, China \\ Correspondence: Huijun Yang, Faculty of International Tourism and Management, City University of Macau, \\ SAR, China. Tel: 853-85902528. E-mail: juneyanghuijun@gmail.com
}

Received: May 9, 2017 Accepted: May 20, 2017 Online Published: May 29, 2017

doi:10.5539/ijms.v9n3p103 URL: http://doi.org/10.5539/ijms.v9n3p103

\begin{abstract}
This study aims to examine the impact of specific dimensions of tourism impacts on Hong Kong residents' satisfaction with the quality of life. While factor analysis is used to explore the attributes and dimensions of tourism impacts, multiple regression analysis is employed to determine the tourism impacts on residents' satisfaction with the quality of life. It is evident from the results that two of the five dimensions of tourism impacts have positive influence on residents' satisfaction. Image and infrastructure are found to be the important determinant factors in explaining the satisfaction. The impacts of environment, economy, and services in affecting satisfaction seem to be insignificant. In order to maintain tourism sustainability in Hong Kong, the local residents' perception should be taken into consideration. Recommendations are provided to achieve mutual benefits and harmonious development.
\end{abstract}

Keywords: tourism impacts, qauality of life, satisfaction, local residents, Hong Kong

\section{Introduction}

The tourism industry is a major economic pillar of Hong Kong —one of the most popular tourist destinations in the world. Once a community becomes popular with tourists, the local residents in that community are inevitably affected by tourism activities (Kim, Uysal, \& Sirgy, 2013; Uysal et al., 2016). Residents may actively participate in tourism activities when they perceive positive tourism impacts (Gursoy \& Rutherford, 2004). Many studies have indicated that tourism impacts on a destination are economic, sociocultural, and environmental among others (Andereck et al., 2005; Ogorelc, 2009; Nunkoo \& Ramkissoon, 2011; Uysal et al., 2016). Tourism is universally considered as an important industry in improving employment opportunities, tax revenue, and economic diversity (Kim et al., 2013). Negative impacts on quality of life, however, might occur in such a destination. Negative impacts may include crowding, traffic congestion, and environmental pollution (Andereck \& Nyaupane, 2011; Andereck et al., 2005). Tourism can also bring along social problems which could contribute to social and cultural changes in the host community (Perdue, Long, \& Kang, 1995).

Tourism influences people's quality of life in a community (Andereck \& Nyaupane, 2011). The quality of life includes the local residents' perceptions of the objective conditions within the host community (Cutter, 1985). Recently, residents' perception toward tourism impacts on and life quality in a tourist destination have been examined in quite a number of studies (Andereck \& Nyaupane, 2011; Andereck et al., 2005; García, Vázquez, \& Macías, 2015; Kim, Uysal, \& Sirgy, 2013; Woo, Kim, \& Uysal, 2015). Yet few studies have specifically investigated tourism impacts on the quality of life (Andereck \& Nyaupane, 2011). Woo, Kim, \& Uysal (2015) further indicate that residents' perceptions towards tourism impact on satisfaction with quality of life have to be taken into account in the tourism development process.

While residents' satisfaction with quality of life in terms of tourism development has been identified (Allen et al., 1993; Gunn, 1990; Woo, Kim, \& Uysal, 2015; McGehee \& Andereck, 2004), existing studies have failed to look at the impacts of specific tourism dimensions on residents' satisfaction with the quality of life. The studies of residents' perceptions towards tourism and life quality have been mostly conducted in western countries (Andereck \& Nyaupane, 2011; Andereck et al., 2005; García et al., 2015; Kim, Uysal, \& Sirgy, 2013; Woo, Kim, \& Uysal, 2015). Only one study on residents' attitude towards tourism in Hong Kong has been documented (Mok, Slater, \& Cheung, 1991). This study aims to identify the dimensions and attributes of tourism impacts and investigate the impact on Hong Kongers' satisfaction with the quality of life. It will be beneficial to policy 
makers and stakeholders for successful planning in tourism developments and destination management.

\section{Literature Review}

\subsection{Tourism Impacts}

Tourism impacts are often divided into different perspectives: economic, social, cultural, and environmental (Andereck et al., 2005; Kim, Uysal, \& Sirgy, 2013; Ogorelc, 2009; Uysal et al., 2016). Tourism development is commonly viewed as an important set of activities to enhance local economies. Many studies revealed positive together with negative economic impacts of tourism on host communities. The positive economic impacts of tourism include increased employment, investment and business opportunities (García et al., 2015; Gilbert \& Clark, 1997; Kim, Uysal, \& Sirgy, 2013; Liu \& Var, 1986), improved community infrastructure, and standard of living (Haralambopoulos \& Pizam, 1996; Lankford \& Howard, 1994). In regard to the negative impact of tourism, the evidence includes the increased prices of goods and services (Haralambopoulos \& Pizam, 1996), increased price of land and housing (Harrill \& Potts, 2003).

Tourism is extensively regarded as an economic development tool for the local community, providing factors that may improve quality of life (Andereck et al., 2005; Kandampully, 2000; Kiriakidou \& Gore, 2005). Although economic benefits are often assumed to largely improve the quality of life, socio-cultural factors may not always be as positive (Liu \& Var, 1986), such as increase in traffic jams, parking problems, downtown crimes town, and changes in hosts' lifestyle (Tosun, 2002; Brunt \& Courtney, 1999; McCool \& Martin, 1994). Puczkó \& Rátz (2000) emphasize that on one hand incorrect tourism development may lead to increased stress on the community and to a negative change in the destinations' socio-cultural and physical characteristics. If there is an imbalance, conflicts may occur (Andereck et al., 2005); on the other, tourism can also produce positive socio-cultural effects, such as increase in the community services, recreational and cultural facilities, cultural events and cultural exchanges (Gilbert \& Clark, 1997; McCool \& Martin, 1994; Perdue et al., 1990). Furthermore, some studies (Goodwin, 2006; Nyaupane et al., 2006; Pagdin, 1995) focus on the role that tourism plays in terms of social and cultural preservation, revitalization of ethic culture, and promotion of indigenous arts and crafts industries in the host regions.

Tourism helps create a greater awareness and appreciation for the need to preserve the environment to capture its natural beauty for tourist purposes, and increase investment in the environmental infrastructure of the tourist destination (Var \& Kim, 1990). Tourism is often considered as a clean industry though it is not always the case. It may cause significant environmental damage because tourism is often developed in the attractive but fragile environments. Tourism growth might severely affect environmental quality (Hassan, 2000), such as disturbance and destruction of flora and fauna, air and water pollution (Andereck et al., 2005; Brunt \& Courtney, 1999), and litter and waste problems (Lankford, 1994), and the depletion of wildlife (Andereck, 1995).

\subsection{Quality of Life and Satisfaction}

Quality of life is defined as person's evaluations of the degree to which his or her needs, goals and wishes have been fulfilled (Frisch, 2000). Rejeski \& Mihalko (2001) indicate that quality of life is a conscious cognitive judgment of satisfaction with one's life. Quality of life is regarded as equivalent to subjective well-being or life satisfaction (Shackman et al., 2005), and the understanding of residents' perceived satisfaction with the environment in which they live (Moscardo, 2009). Once a community becomes a destination, the quality of life is affected by tourism development (Uysal et al., 2016; Uysal et al., 2012). Andereck et al. (2005) have developed measure of perceived impact of tourism on community quality of life by assembling a large set of items (38) (e.g., preserving peace and quiet, feeling safe, clean air and water, city services such as police and fire protection). Woo (2013) found that satisfaction positively affects residents' quality of life in that the more positive perceptions of tourism impacts the greater their satisfaction with the community, emotional life, and health and safety. Quality of life and satisfaction have received more attention in tourism study (Perdue, Tyrrell, \& Uysal, 2010; Uysal et al., 2012; Woo et al., 2015). Policy makers are increasingly interested in the effects of regional, community, and neighborhood development through both objective and subjective indicators of community quality of life (Woo et al., 2015). Therefore, quality of life and satisfaction toward tourism impacts should be taken into serious consideration.

Since tourism relies heavily upon the goodwill of the residents, local support is essential to its development, successful operation, and sustainability of the industry in the long term (Vargas-Sánchez et al., 2011; Aguiló \& Roselló, 2005; Sheldon \& Abenoja, 2001). In fact, the sense of residents' community attachment not only influences residents' perceptions of the impacts of tourism (McCool \& Martin, 1994; Um \& Crompton, 1987; Sheldon \& Var, 1984), but also the relationship between residents and tourists. If residents' attitudes are favorable towards the tourism impacts, then they will probably support additional local tourism development and 
show more hospitality to tourists. It is valuable that tourists are more favorably attracted by destinations in which residents are more friendly, honest and hospitable (Fallon \& Schofield, 2006). Therefore, the local residents must increasingly be involved and given an active role, participating in the planning and management of local tourism policy (Simpson \& Bretherton, 2009; Dyer et al., 2007) to obtain their agreement and support. City planners and promoters need to monitor stakeholders' perception of the value of tourism over time and how positive or negative impacts may influence residents' satisfaction (Woo et al., 2015).

\section{Methodology}

This study has adopted the quantitative research method to assess the factors affecting tourism impacts. The measurement of factors affecting tourism impacts is a questionnaire modified from the tourism impact model consisting of 38 items proposed by Andereck et al. (2005). An open-ended question is included in the questionnaire to examine what factors affect tourism impacts in Hong Kong apart from the 38 items above.

Also in this study, to make this tourism impact model applicable to the residents in Hong Kong, an item-screening test used by $\mathrm{Chu} \&$ Choi (2000) is adopted to extract the important items that most effectively represent the factors affecting tourism impacts. The questionnaire was reviewed and validated by item-screening test by 15 academic researchers from Hong Kong. The 15 academic researchers were asked to rate each of the 38 tourism impacts on a seven-point Likert scale ranging from "extremely unrepresentative" to "extremely representative". Altogether 23 out of 38 items were selected to represent the local residents' perceptions of tourism impacts in Hong Kong. Two tourism impact items- "Tourism results in the creation of unauthentic cultural experiences" and "Tourism has heightened tension between residents and tourists" were identified based on a review of relevant literature and the open-ended question. Hence, the final version of the questionnaire includes a set of 25 items of tourism impacts. The questionnaire was translated into Chinese by a third party professional bilingual translator and printed in English and Chinese.

The survey was conducted based on the convenience sampling in Hong Kong on January 2017. In order to avoid bias of population homogeneity and to obtain comprehensive data collection, the local resident population was divided into four groups or strata, based on geography-Hong Kong Island, Kowloon, New Territories and Lantau Island. As for the sample size, Hair et al. (2002) suggest that a ratio of 5:1 criterion (ratio of respondents to items) is suitable for most types of multiple correlation statistics. Thus, a total of 300 questionnaires were distributed to local residents for the 25 tourism impacts on a seven-point Likert scale, with 1 representing "Extremely Unimportant" to 7 "Extremely important".

To analyze the data, SPSS version 22.0 was used. 244 questionnaires were collected from the distribution of 300 questionnaires. The respondents rate is $81.3 \%$. Descriptive statistics was calculated for the demographic characteristics of local residents. Of the 244 respondents, $34.4 \%$ were male and $65.6 \%$ were female. The most frequent age group was the 18-29 group, accounting for $78.3 \%$ of the sample, followed by the 30-39 age group (9.8\%), 40-49 age group (5.7\%), 50-59 age group (5.3\%) and the 60 or above age group $(0.8 \%)$. In terms of education, $42.2 \%$ graduated from vocational college, $32.8 \%$ graduated from high school or less, $20.1 \%$ had Bachelor's degrees and $4.9 \%$ were postgraduates (shown in Table 1).

A principal components factor analysis with Varimax Rotation was conducted to extract underlying factors with 25 items. Kaiser- Meyer- Oklin (KMO) of the study is 0.830, and the Bartlett Test of Sphericity is 2431.157, with significant equal to 0.000 . According to Kaiser (1974), if the measure of KMO is over 0.8 , it is considered great. Both statistical data supported the use of factor analysis for these items. "Latent root/ Eigen value" and Scree plot were applied as the criteria for selecting the right number of factors (Hair, Anderson, Tatham, \& Black, 1995). In this study, the sample size is 244 and the average communality is lower than 0.6. A Scree- test plot was obtained to find out the number of dominant factors. Based on the graphic display of the plot, it was determined that five factors were to be extracted. 25 items had factor loading over 0.4 and all those items were retained, generating five dimensions of tourism impacts. They are "Environment"; "Image"; "Infrastructure"; "Economy"; and "Services". In order to test the reliability and internal consistency of each factor, reliability analysis (Cronbach's Alpha) was conducted. The results showed that Alphas coefficients of the five dimensions ranged from 0.644 to 0.859 . The Cronbach alpha coefficient should be higher than 0.6 (Malhotra, 2007) which is considered acceptable as an indication of reliability for basic research (shown in Table 2). 
Table 1. Profile of respondents of main survey

\begin{tabular}{|c|c|c|}
\hline Items & Characteristics & Percent $(\%)$ \\
\hline \multirow[t]{2}{*}{ Gender } & Male & $34.4 \%$ \\
\hline & Female & $65.6 \%$ \\
\hline \multirow[t]{5}{*}{ Age } & $18-29$ & $78.3 \%$ \\
\hline & $30-39$ & $9.8 \%$ \\
\hline & $40-49$ & $5.7 \%$ \\
\hline & $50-59$ & $5.3 \%$ \\
\hline & $60+$ & $0.8 \%$ \\
\hline \multirow[t]{5}{*}{ Education } & High school or less & $32.8 \%$ \\
\hline & Vocational college & $42.2 \%$ \\
\hline & 4 years of university & $20.1 \%$ \\
\hline & Postgraduate & $4.9 \%$ \\
\hline & Doctor & $0.0 \%$ \\
\hline \multirow[t]{8}{*}{ Industry } & Tourism & $3.7 \%$ \\
\hline & Retails & $7.8 \%$ \\
\hline & Servicing & $19.3 \%$ \\
\hline & Finance & $5.3 \%$ \\
\hline & Education & $11.1 \%$ \\
\hline & Manufacturing & $5.3 \%$ \\
\hline & Accounting & $13.5 \%$ \\
\hline & Other & $34.0 \%$ \\
\hline \multirow[t]{5}{*}{ Industry experience } & Less than 5 years & $68.9 \%$ \\
\hline & $6-10$ years & $15.6 \%$ \\
\hline & $11-15$ years & $7.0 \%$ \\
\hline & $16-20$ years & $2.9 \%$ \\
\hline & More than 20 years & $5.7 \%$ \\
\hline \multirow[t]{4}{*}{ Geography } & Hong Kong Inland & $14.3 \%$ \\
\hline & Kowloon & $33.6 \%$ \\
\hline & New Territories & $47.5 \%$ \\
\hline & Lantau & $4.5 \%$ \\
\hline
\end{tabular}

Table 2. Factor analysis of Hong Kong residents' perceptions towards tourism impacts ( $N=244)$

\begin{tabular}{|c|c|c|c|c|c|c|}
\hline Factors \& Attributes & $\begin{array}{l}\text { Factor } \\
\text { loading }\end{array}$ & Communality & $\begin{array}{l}\text { Eigen } \\
\text { value }\end{array}$ & $\begin{array}{l}\text { Variance } \\
\text { explained }\end{array}$ & Mean & $\begin{array}{l}\text { Reliability } \\
\text { coefficient }\end{array}$ \\
\hline Factor 1: Environment & & & 5.466 & 22.774 & 5.102 & .859 \\
\hline 19. Tourism creates an increase in traffic congestion & .748 & .714 & & & & \\
\hline 20. Tourism increases noise pollution and litter & .745 & .623 & & & & \\
\hline 21. Tourism results in over-crowding & .752 & .650 & & & & \\
\hline 22. Tourism has increased crime & .760 & .677 & & & & \\
\hline 23. Tourism brings the concern about safety & .686 & .568 & & & & \\
\hline $\begin{array}{l}\text { 24. Tourism results in the creation of unauthentic cultural } \\
\text { experiences }\end{array}$ & 652 & .562 & & & & \\
\hline $\begin{array}{l}25 . \text { Tourism has heightened tension between residents and } \\
\text { tourists }\end{array}$ & .746 & .582 & & & & \\
\hline Factor 2: Image & & & 4.068 & 16.949 & 4.626 & .823 \\
\hline 08. Tourism improves the area's appearance & .597 & .526 & & & & \\
\hline 09. Tourism preserves historic buildings and monuments & .805 & .667 & & & & \\
\hline $\begin{array}{l}\text { 10. Tourism preserves the natural environment/does not cause } \\
\text { ecological decline }\end{array}$ & .811 & .701 & & & & \\
\hline $\begin{array}{l}\text { 11. Tourism increases demand for historical and cultural } \\
\text { exhibits }\end{array}$ & .779 & .661 & & & & \\
\hline 12. Tourism promotes cultural exchange & .657 & 617 & & & & \\
\hline Factor 3: Infrastructure & & & 2.115 & 8.812 & 4.681 & .738 \\
\hline 03. Tourism contributes to income and standard of living & .537 & .546 & & & & \\
\hline 04 . Tourism increases tax revenues & .709 & .597 & & & & \\
\hline 05. Tourism improves public utilities infrastructure & .728 & .637 & & & & \\
\hline 06. Tourism increases opportunities for shopping & .579 & .424 & & & & \\
\hline 07. Tourism improves transport infrastructure & .566 & .600 & & & & .644 \\
\hline
\end{tabular}




\begin{tabular}{|c|c|c|c|c|c|c|}
\hline Factor 4: Economy & & & 1.393 & 5.806 & 5.371 & \\
\hline 01. Tourism increases employment opportunities & .758 & .676 & & & & .721 \\
\hline 02. Tourism improves the local economy & .835 & .734 & & & & \\
\hline Factor 5: Services & & & 1.289 & 5.370 & 4.798 & 663 \\
\hline $\begin{array}{l}\text { 14. Tourism has increased availability of recreation } \\
\text { facilities/opportunities }\end{array}$ & .487 & .550 & & & & \\
\hline $\begin{array}{l}\text { 15. Tourism improves understanding and image of different } \\
\text { communities/cultures }\end{array}$ & .550 & .622 & & & & \\
\hline 16. Tourism improves quality of police and fire protection & .527 & .563 & & & & \\
\hline 17. Tourism increases the price of land and housing & .575 & .483 & & & & \\
\hline $\begin{array}{l}\text { 18. Tourism increases price and shortages of goods and } \\
\text { services }\end{array}$ & .552 & .562 & & & & \\
\hline Total variance explained & & & & 59.711 & & \\
\hline
\end{tabular}

Note. $\mathrm{KMO}=.830$, Bartlett's Test of Sphericity: chi-square $=2431.157, \mathrm{p}<.000$.

Table 3. Mean scores of the five tourism impacts dimensions

\begin{tabular}{llll}
\hline \multicolumn{2}{l}{ Tourism impacts dimensions } & Mean & Ranking \\
\hline Factor 4 & Economy & 5.371 & 1 \\
Factor 1 & Environment & 5.102 & 2 \\
Factor 5 & Services & 4.798 & 3 \\
Factor 3 & Infrastructure & 4.681 & 4 \\
Factor 2 & Image & 4.626 & 5 \\
\hline
\end{tabular}

Mean scores for the five dimensions are shown in Table 3. Among all mean scores of these five dimensions, the Hong Kong residents agreed "Economy" was the most important factor (5.371), followed by "Environment" (5.102), "Services" (4.798), "Infrastructure" (4.681). "Image" was loaded as the least important among the five with a mean of 4.626 .

Regression analysis was used having satisfaction with quality of life as the dependent variable and tourism impacts as the independent variable (shown in Table 4). According to the adjusted R-squared value of 0.322 of this regression model, $32.2 \%$ of the variation of the overall satisfaction was explained by the five independent variables of tourism impacts. The significant $F$ ratio $(F=24.099, p<.001)$ indicated a satisfactory goodness-of-fit. Two independent variables, image $(t=8.345, \mathrm{p}<.001)$ and infrastructure $(\mathrm{t}=4.976, \mathrm{p}<.001)$ were found to exert significant positive effect on satisfaction with quality of life. The environment $(t=-.582, p$ $=.115)$, economy $(\mathrm{t}=.250, \mathrm{p}=.803)$, and services $(\mathrm{t}=1.509, \mathrm{p}=.132)$ on satisfaction of quality of life were deemed insignificant.

Table 4. Regression results

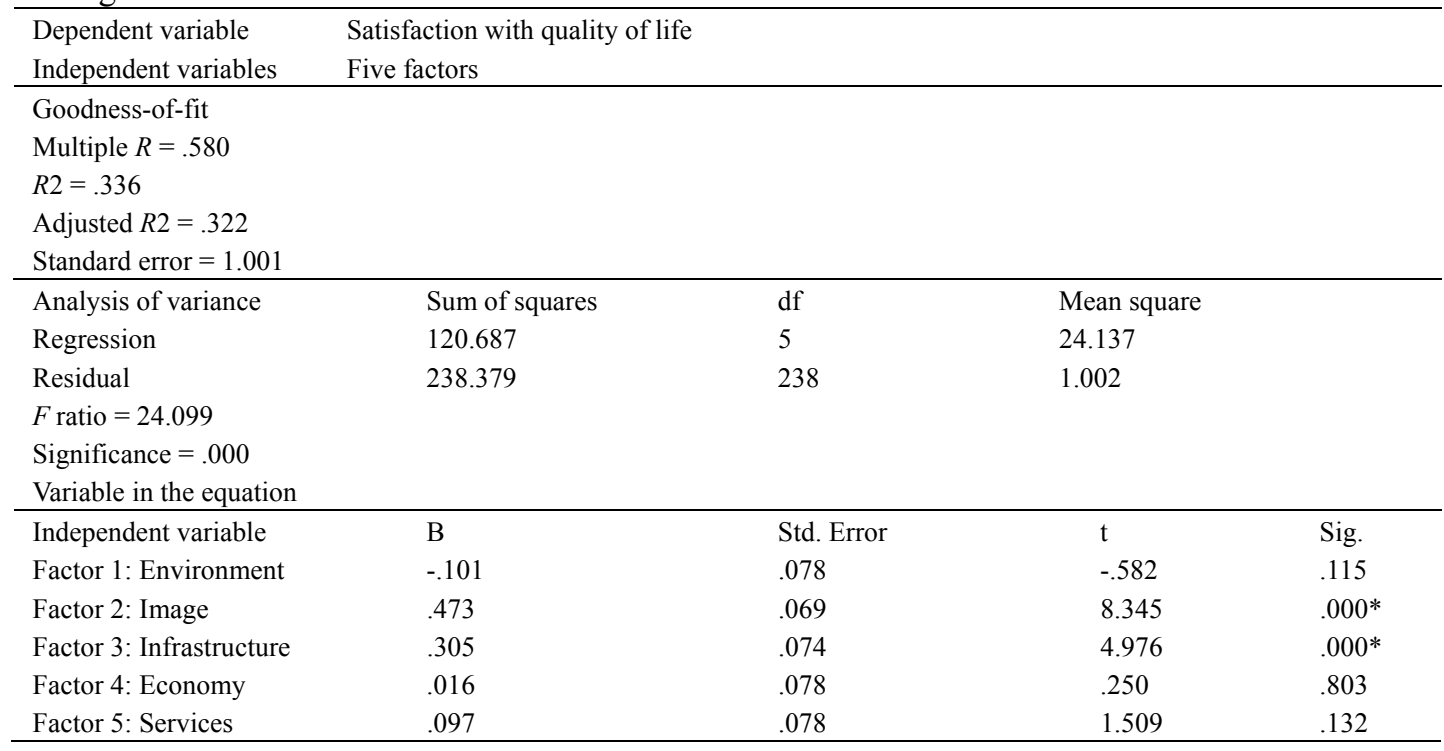

Note. ${ }^{*} \mathrm{p} \leq .001$. 
Regression analysis was used having satisfaction with quality of life as the dependent variable and tourism impacts as the independent variable (shown in Table 4). According to the adjusted R-squared value of 0.322 of this regression model, $32.2 \%$ of the variation of the overall satisfaction was explained by the five independent variables of tourism impacts. The significant $F$ ratio $(F=24.099, p<.001)$ indicated a satisfactory goodness-of-fit. Two independent variables, image $(\mathrm{t}=8.345, \mathrm{p}<.001)$ and infrastructure $(\mathrm{t}=4.976, \mathrm{p}<.001)$ were found to exert significant positive effect on satisfaction with quality of life. The environment $(t=-.582, p$ $=.115)$, economy $(\mathrm{t}=.250, \mathrm{p}=.803)$, and services $(\mathrm{t}=1.509, \mathrm{p}=.132)$ on satisfaction of quality of life were deemed insignificant.

In addition, the standardized $\beta$ value was used to investigate the relative importance of each of the five independent variables in contributing to quality of life. Image $(\beta=.473)$, with the highest $\beta$ value, was the most important determining factor in explaining satisfaction with quality of life, followed by Infrastructure $(\beta=.305)$, Services $(\beta=.097)$, and Economy $(\beta=.016)$.

\section{Discussion and Recommendations}

The findings of this study show that Hong Kong residents' perceptions of tourism impacts significantly influence their satisfaction of quality of life. Two tourism impacts dimensions, image and infrastructure, were identified as having significant impact on satisfaction with quality of life. Insignificant, however, were the impacts of environment, economy, and services in affecting satisfaction with quality of life.

Tourism draws attention to issues relating to human impacts on the environment. The pollution, traffic congestion, over-crowding, safety concern, and tension between residents and tourists, are the bases on which residents judge their satisfaction with quality of life. The notion among the residents that tourism development would lead to traffic problems was found to be consistent with some studies (Amuquandoh, 2010; Dickinson, Robbions \& Fletcher, 2009). If there is an imbalance between tourists and local residents, conflicts may arise (Andereck et al., 2005). Resource competition between tourists and local residents may increase tension and even elevate political risk (Liu, 2014). This dimension was not significant, probably because much concern has been expressed about increased level of over-crowding, traffic congestion, and consequent effects on the environment and human health and safety in Hong Kong.

Tourism-generated proceeds contribute to a significant revenue source by increasing employment, government income, and local economy (Oh, 2005). Contributions towards the local economy and employment have been well documented in many studies (García et al., 2015; Gilbert \& Clark, 1997; Kim, Uysal, \& Sirgy, 2013). In this study, however, the impact of economy in affecting satisfaction with quality of life was insignificant, which contradicts those identified in the previous studies. If the economy is too heavily dependent on the tourism sector, tourism development may not lead to impressive economic growth, since the overall contribution of tourism to the economy could be reduced by many factors. Chang, Khamkaew, \& McAleer (2009) indicate that some of the impacts of economy have not always been regarded as positive, such as increased income inequality, inefficient resource allocation, and other harmful externalities. Therefore, the impact of economy does not always lead to residents' satisfaction with quality of life.

Residents felt the impacts of services in affecting satisfaction with quality of life were insignificant. Services, in this study, include city services, increasing the price and shortages of goods and services, and increasing land and housing which tourism impacts offered. Revenue generated by tourism does not always benefit the local community, as tourism can push up local property prices and the cost of goods and services. The results support the findings of earlier research on tourism's negative effects, such as the increases in the cost of living (Ko \& Stewart, 2002), prices of goods and services (Haralambopoulos \& Pizam, 1996; Weaver \& Lawton, 2001), and price of land and housing (Burriel, 2011; Harrill \& Potts, 2003). Residents felt that tourism has a negative influence on city services, including the availability of recreation facilities, police and fire protection. Overcrowding is a common problem for tourist destinations and residents often curtailed their activities due to overcrowding (Rothman, 1978). Therefore, residents felt that tourism exacerbates some problems such as overcrowding at outdoor recreation facilities (Johnson et al., 1994), and the presence of criminal activity (Wall \& Mathieson, 2006). Puczkó \& Rátz (2000) indicate that incorrect tourism development can lead to increased stress on the community and to a negative change in the destinations' socio-cultural and physical characteristics.

The results of the study showed that image and infrastructure are the significant factors in influencing residents' satisfaction with quality of life. These findings support Kim \& Patrick (2005) study, which identified positive impacts of tourism, such as tourism resource development, image enhancement, tourism infrastructure development, etc. "Image" such as destination's appearance, historic buildings, natural environment, culture and history, are found to be the most significant factors in influencing satisfaction with quality of life. Tourism can 
help enhance the community image by preserving natural and cultural resources, and improving area's appearance (Andereck et al., 2005). Infrastructure such as public utilities infrastructure and transport infrastructure facilitate enjoyable living standard for residents. Tourism development has improved the quality of life by increasing the destination' infrastructure and services (Nunkoo \& Ramkissoon, 2011). The improvements of destination infrastructure will enhance residents life. Therefore, infrastructure contribute significantly to the residents' satisfaction with quality of life. The study shows that perception of the positive tourism impact was an important determinant in satisfaction with community well-being, suggesting that internal marketing techniques designed to inform residents of the benefits they receive from tourism may be helpful in gaining the residents' support for the development, successful operation, and sustainability of tourism.

It is evident from the results that two of the five dimensions of tourism impacts have positive influence on residents' satisfaction with quality of life in Hong Kong. Planners and policy makers should know how residents perceive tourism impacts and how it influence their satisfaction. If the current level of tourism development influences quality of life negatively, residents may not support future tourism development in Hong Kong. Policies should enhance the positive dimensions and mitigate the negative dimensions to improve the residents' satisfaction with the quality of life derived from those tourism dimensions. Planners need to develop a short-term perspective of tourism benefits as well as a long-term perspective of residents' quality of life (Kim et al., 2013). Promotion of the positive impacts may help to sway the opinion of residents who perceive that they have little to gain benefit from tourism.

Residents' perceived value of quality of life is regarded as a predictor of future tourism development (Woo et al., 2015). Enhancement of the life quality has become the overall purpose of tourism development by addressing the economic, social, cultural, environmental impacts of tourism (Mike \& Markus, 2014). Quality of life of local residents is a major concern for policy makers (Uysal et al., 2016). Therefore, to make the destination more sustainable and competitive, government planners and tourism developers should strive to increase Hong Kong residents' quality of life.

Future research may consider enlarging the sample size and collecting data from Hong Kong eighteen districts that may display a differing perspective of the tourism impacts in Hong Kong. Residents' perceptions regarding tourism impacts, quality of life, and life satisfaction might be different, depending on the residents' personality and demographic information as well as the different districts. For instance, if living in Islands District where there is not heap of popular tourist attractions, residents are more likely to positively perceive their satisfaction with quality of life. Therefore, in future research, residents' characteristics should be considered.

\section{References}

Aguiló, E., \& Roselló, J. (2005). Host Community perceptions a cluster analysis. Annals of Tourism Research, 32(4), 925-941. https://doi.org/10.1016/j.annals.2004.11.004

Allen, L. R., Hafer, H. R., Long, R., \& Perdue, R. R. (1993). Rural residents' attitudes toward recreation and tourism development. Journal of Travel Research, 31(4), 27-33. https://doi.org/10.1177/004728759303100405

Amuquandoh, F. E. (2010). Residents' perceptions of the environmental impacts of tourism in the Lake Bosomtwe Basin, Ghana. Journal of Sustainable Tourism, 18(2), 223-238. https://doi.org/10.1080/09669580903298531

Andereck, K. L. (1995). Environmental Consequences of Tourism: A Review of Recent Research. In Linking Tourism, the Environment, and Sustainability. Annual Meeting of the National Recreation and Park Association, pp. 77-81, General Technical Report No, INT-GTR-323.

Andereck, K. L., \& Nyaupane, G. P. (2011). Exploring the Nature of Tourism and Quality of Life Perceptions among Residents. Journal of Travel Research, 50(3), 248-260. https://doi.org/10.1177/0047287510362918

Andereck, K. L., Valentine, K. M., Knopf, R. C., \& Vogt, C. A. (2005). Residents' perceptions of community tourism impacts. Annals of Tourism Research, 32, 1056-1076. https://doi.org/10.1016/j.annals.2005.03.001

Brunt, P., \& Courtney, P. (1999). Host Perceptions of Sociocultural Impacts. Annals of Tourism Research, 26, 493-515. https://doi.org/10.1016/S0160-7383(99)00003-1

Burriel, E. L. (2011). Subversion of land-use plans and the housing bubble in Spain. Urban Research \& Practice, 4(3), 232-249. https://doi.org/10.1080/17535069.2011.616743

Chang, C. L., Khamkaew, T., \& McAleer, M. (2009). A Panel Threshold Model of Tourism Specialization and Economic Development. https://doi.org/10.2139/ssrn.1496324 
Chu, R. K. S, \& Choi, T. (2000). An importance-performance analysis of hotel selection factors in the Hong Kong hotel industry: a comparison of business and leisure travelers. Tourism Management, 21(4), 363-377. https://doi.org/10.1016/S0261-5177(99)00070-9

Cutter, S. L. (1985). Rating Places: A Geographer's View on Quality of Life. Washington, DC: Resource Publications in Geography, the Association of American Geographers.

Dickinson, J. E., Robbions, D., \& Fletcher, J. (2009). Representation of transport: A Rural Destination Analysis. Annals of Tourism Research, 36(1), 103-123. https://doi.org/10.1016/j.annals.2008.10.005

Dyer, P., Gursoy, D. Sharma, B., \& Carter, J. (2007). Structural Modeling of Resident Perceptions of Tourism \& Associated Development on the Sunshine Coast, Australia. Tourism Management, 28(2), 409-422. https://doi.org/10.1016/j.tourman.2006.04.002

Fallon, P., \& Schofiel, P. (2006). The dynamics of destination attribute importance. Journal of Business Research, 59(6), 709-713. https://doi.org/10.1016/j.jbusres.2006.01.007

Frisch, M. B. (2000). Improving mental and physical health care through quality of life therapy and assessment. In E. Diener \& D. R. Rahtz (Eds.), Advances in quality of life theory and research (pp. 207-241). Dordrecht, Netherlands: Kluwer Academic Press. https://doi.org/10.1007/978-94-011-4291-5_10

García, F. A., Vázquez, A. B., \& Macías, R. C. (2015). Resident's attitudes towards the impacts of tourism. Tourism Management Perspectives, 13, 33-40. https://doi.org/10.1016/j.tmp.2014.11.002

Gilbert, D., \& Clark, M. (1997). An Exploratory Examination of Urban Tourism Impact, with Reference to Residents Attitudes in the Cities of Canterbury and Guildford. Cities, 14, 343-352. https://doi.org/10.1016/S0264-2751(97)00025-5

Goodwin, H. (2006). Measuring and reporting the impact of tourism on poverty. Cutting Edge Research in Tourism-New Directions, Challenges and Applications School of Management. University of Surrey, UK 6-9 June 2006.

Gunn, C. A. (1990). The New Recreation-Tourism Alliance. Journal of Park and Recreation Administration, 8(1), $1-9$.

Gursoy, D., \& Rutherford, D. G. (2004). Host attitude toward tourism: An improved structural model. Annals of Tourism Research, 31, 495-516. https://doi.org/10.1016/j.annals.2003.08.008

Hair, J. F. Jr., Anderson, R. E., Tatham, R. L., \& Black, W. C. (1995). Multivariate data analysis with readings (4th ed.). Englewood Cliffs, NJ: Prentice-Hall.

Hair, J. F., Anderson, S. E., Tatham, R. L., \& Black, W. C. (2002). Multivariate data analysis. New York: Prentice-Hall International.

Haralambopoulos, N., \& Pizam. A. (1996). Perceived Impacts of Tourism: The Case of Samos. Annals of Tourism Research, 23, 503-526. https://doi.org/10.1016/0160-7383(95)00075-5

Harrill, R., \& Potts, T. D. (2003). Tourism planning in historic districts. Attitudes toward tourism development in Charleston. Journal of the American Planning Association, 69(3), 233-244. https://doi.org/10.1080/01944360308978017

Hassan, S. S. (2000). Determinants of Market Competitiveness in an Environmentally Sustainable Tourism Industry. Journal of Travel Research, 38(3), 239-245. https://doi.org/10.1177/004728750003800305

Johnson, J., Snepenger, D., \& Akis, S. (1994). Residents' Perceptions of Tourism Development. Annals of Tourism Research, 21, 629-642. https://doi.org/10.1016/0160-7383(94)90124-4

Kaiser, H. F. (1974). An index of factorial simplicity. Psychometrika, 39, 31-36. https://doi.org/10.1007/BF02291575

Kandampully, J. (2000). The impact of demand Fluctuation on the Quality of Service: A Tourism Industry Example. Managing Service Quality, 10(1), 10-18. https://doi.org/10.1108/09604520010307012

Kim, K., Uysal, M., \& Sirgy, M. J. (2013). How does tourism in a community impact the quality of life of community residents? Tourism Management, 36, 527-540. https://doi.org/10.1016/j.tourman.2012.09.005

Kim, S. S., \& Patrick, J. E. (2005). Residents' perceptions on impacts of the FIFA 2002 World Cup: the case of Seoul as a host city. Tourism Management, 25(1), 25-38. https://doi.org/10.1016/j.tourman.2003.09.013

Kiriakidou, O., \& Gore, J. (2005). Learning by example: benchmarking organizational culture in hospitality, 
tourism and leisure SMEs. Benchmarking: An International Journal, 12(3), 192-206. https://doi.org/10.1108/14635770510600320

Ko, D. W., \& Stewart, W. P. (2002). A structural equation model of residents' attitudes for tourism development. Tourism Management, 23, 521-530. https://doi.org/10.1016/S0261-5177(02)00006-7

Lankford, S. (1994). Attitudes and perceptions toward tourism and rural region a development. Journal of Travel Research, 32(3), 35-43. https://doi.org/10.1177/004728759403200306

Lankford, S., \& D. Howard. (1994). Developing a Tourism Impact Attitude Scale. Annals of Tourism Research, 21, 121-139. https://doi.org/10.1016/0160-7383(94)90008-6

Liu, J. (2014). Hong Kong tensions rise over "parallel traders". Retrieved from http://www.bbc.com/news/business-28093730

Liu, J., \& Var, T. (1986). Resident Attitudes Towards Tourism Impacts in Hawaii. Annals of Tourism Research, 13, 193-214. https://doi.org/10.1016/0160-7383(86)90037-X

Malhotra, N. K. (2007). Marketing Research. Upper Saddle River, New Jersey: Pearson Prentice Hall. https://doi.org/10.1108/S1548-6435(2007)3

McCool, S., \& S. Martin. (1994). Community Attachment and Attitudes towards Tourism Development. Journal of Travel Research, 32(3), 29-34. https://doi.org/10.1177/004728759403200305

Mike, P., \& Markus, S. (2014).Tourism entrepreneurs' perception of quality of life: An explorative study. Tourism Analysis, 19(6), 731-740. https://doi.org/10.3727/108354214X14146846679484

Mok, C., Slater, B., \& Cheung, V. (1991). Residents' attitudes towards tourism in Hong Kong. International Journal of Hospitality Management, 10(3), 289-293. https://doi.org/10.1016/0278-4319(91)90061-L

Moscardo, G. (2009). Tourism and quality of life: Towards a more critical approach. Tourism and Hospitality Research, 9, 159-170. https://doi.org/10.1057/thr.2009.6

Nunkoo, R., \& Ramkissoon, H. (2011). Residents' satisfaction with community attributes and support for tourism. Journal of Hospitality \& Tourism Research, 35(2), 171-190. https://doi.org/10.1177/1096348010384600

Nyaupane, G. P., Morais, D. B., \& Dowler, L. (2006). The role of community involvement and number/type of visitors on tourism impacts: A controlled comparison of Annapurna, Nepal and Northwest Yunnan, China. Tourism Management, 27(6), 1373-1385. https://doi.org/10.1016/j.tourman.2005.12.013

Ogorelc, A. (2009). Residents' perceptions of tourism impacts and sustainable tourism development. International Journal of Sustainable Economy, 1(4), 373-387. https://doi.org/10.1504/IJSE.2009.024763

Oh, C. O. (2005). The contribution of tourism development to economic growth in the Korean economy. Tourism Management, 26, 39-44. https://doi.org/10.1016/j.tourman.2003.09.014

Pagdin, C. (1995). Assessing tourism impacts in the third world: a Nepal case study. Progress in Planning, 44(3), 185-266. https://doi.org/10.1016/S0305-9006(95)00004-6

Perdue, R. R., Long, P. T., \& Kang, Y. S. (1995). Resident support for gambling as a tourism development strategy. Journal of Travel Research, 34(2), 3-11. https://doi.org/10.1177/004728759503400203

Perdue, R. R., Tyrrell, T., \& Uysal, M. (2010). Understanding the value of tourism: conceptual divergence. In D. Pearce \& R. Butler (Eds.), Tourism research: A 20:20 vision (pp. 123-134). Oxford: Goodfellow Publishers.

Perdue, R., Long, P., \& Allen, L. (1990). Resident Support for Tourism Development. Annals of Tourism Research, 17, 586-599. https://doi.org/10.1016/0160-7383(90)90029-Q

Puczkó, L., \& Rátz, T. (2000). Tourist and Resident Perceptions of the Physical Impacts of Tourism at Lake Balaton, Hungary: Issues for journal Sustainable Tourism Management. Journal of Sustainable Tourism, 8(6), 458-478. https://doi.org/10.1080/09669580008667380

Rejeski, W., \& Mihalko, S. (2001). Physical activity and quality of life in older adults. Journals of Gerontology, Series A: Biological Sciences \& Medical Sciences, 56, 23-35. https://doi.org/10.1093/gerona/56.suppl_2.23

Rothman, R. A. (1978). Residents and transients: community reaction to seasonal visitors. Journal of Travel Research, 16(3), 8-13. https://doi.org/10.1177/004728757801600303

Shackman, G., Liu, Y., \& Wang, X. (2005). Measuring quality of life using free and public domain data. Social Research Update, 47. 
Sheldon, P. J., \& Abenoja, T. (2001). Resident attitudes in a mature destination: the case of Waikiki. Tourism Management, 22(5), 435-443. https://doi.org/10.1016/S0261-5177(01)00009-7

Sheldon, P. J., \& Var, T. (1984). Resident Attitudes to Tourism in North Wales. Tourism Management, 5, 40-47. https://doi.org/10.1016/0261-5177(84)90006-2

Simpson, K., \& Bretherton, P. (2009). The impact of community attachment on host society attitudes and behaviours towards visitors. Tourism and Hospitality Planning and Development, 6(3), 235-246. https://doi.org/10.1080/14790530903363431

Tosun, C. (2002). Host Perceptions of Impacts: A Comparative Tourism Study. Annals of Tourism Research, 29, 231-253. https://doi.org/10.1016/S0160-7383(01)00039-1

Um, S., \& Crompton, J. L. (1987). Measuring Resident's Attachment Levels in a Host Community. Journal of Travel Research, 26(2), 27-29. https://doi.org/10.1177/004728758702600105

Uysal, M., Perdue, R., \& Sirgy, R. (2012). Handbook of tourism and quality of life research: Enhancing the lives of tourists and residents of host communities. Dordrecht, the Netherlands: Springer. https://doi.org/10.1007/978-94-007-2288-0

Uysal, M., Sirgy, M. J., Woo, E., \& Kim, H. (2016). Quality of life (QOL) and well-being research in tourism. Tourism Management, 53, 244-261. https://doi.org/10.1016/j.tourman.2015.07.013

Var, J., \& Kim. S. (1990). Research Methods for Leisure and Tourism: A Practical Guide (3rd ed.). Harlow: Prentice Hall.

Vargas-Sánchez, A., Porras-Bueno, N., \& De los Ángeles Plaza-Mejía, M. (2011). Explaining residents' attitudes to tourism. Is a universal model possible? Annals of Tourism Research, 38(2), 460-480. https://doi.org/10.1016/j.annals.2010.10.004

Vickerman, S. (1988). Simulating tourism and economic growth by featuring new wildlife recreation opportunities. Transactions of the 53rd North American Wildlife Natural Resources Conference, 414-423.

Wall, G., \& Mathieson, A. (2006). Tourism: Changes, Impacts, and Opportunities. Upper Saddle River, NJ: Pearson Education.

Weaver, D., \& Lawton, L. (2001). Resident perceptions in the urban-rural fringe. Annals of Tourism Research, 28, 349-458. https://doi.org/10.1016/S0160-7383(00)00052-9

Woo, E. (2013). The impacts of tourism development on stakeholders' quality of life (QOL): A comparison between community residents and employed residents in the hospitality and tourism industry. Unpublished Dissertation. Blacksburg, Virginia: Virginia Polytechnic Institute and State University.

Woo, E., Kim, H., \& Uysal, M. (2015). Life satisfaction and support for tourism development. Annals of Tourism Research, 50, 84-97. https://doi.org/10.1016/j.annals.2014.11.001

\section{Copyrights}

Copyright for this article is retained by the author, with first publication rights granted to the journal.

This is an open-access article distributed under the terms and conditions of the Creative Commons Attribution license (http://creativecommons.org/licenses/by/4.0/). 